\title{
Short Communication: Changes in the Association Between Milk Yield and Age at First Calving in Holstein Cows with Herd Environment Level for Milk Yield
}

\author{
R. Ruiz-Sánchez, ${ }^{*}$ R. W. Blake,† H. M. A. Castro-Gámez,ł F. Sánchez, ${ }^{*}$ H. H. Montaldo,‡ \\ and $H$. Castillo-Juárez ${ }^{\star 1}$ \\ *Departamento de Producción Agrícola y Animal, Universidad Autónoma Metropolitana, Unidad Xochimilco, Calzada del Hueso 1100, \\ Coyoacán, D. F., C. P. 04960, México \\ †Department of Animal Science, Cornell University, Ithaca, NY 14853 \\ ‡Departamento de Genética y Bioestadística, Facultad de Medicina Veterinaria y Zootecnia, Universidad Nacional Autónoma de México, \\ Coyoacán, D. F., C. P. 04510, México
}

\begin{abstract}
The aim of this study was to evaluate the effect of herd environment class on the genetic and phenotypic relationships of mature equivalent milk yield (MY) on age at first calving (AFC). Data analyzed were 248,230 first parity records of Holstein cows, daughters of 588 sires in 3,042 herds in the United States. Heritability for AFC was $0.33 \pm 0.01$ and $0.20 \pm 0.01$ in high and low environment herds, respectively, and $0.47 \pm 0.01$ in the complete data set. The correlation between AFC sires' predicted breeding values of low and high classes was 0.69. Genetic correlations between MY and AFC were $-0.52 \pm 0.02$ and $-0.31 \pm 0.03$ in high and low environment herds, respectively, and $-0.44 \pm 0.02$ in the complete data set representing intermediate environments. If selection is based on the whole data set, expected correlated responses for AFC estimated as a result of $1,000 \mathrm{~kg}$ of genetic gain in MY, for high and low herd environment herds were -26.1 and $-15.3 \mathrm{~d}$, respectively, and -32.6 for the complete data set; hence the highest reduction in AFC occurs in intermediate environment herds. Different estimates of the heritability of AFC, the correlation between AFC breeding values of low and high classes as well as changes in the genetic correlation between MY and AFC across environments indicate genotype $\times$ environment interaction. Caution in interpretation is warranted because genetic relationships are dynamic, especially in populations undergoing selection. Current relationships may differ from those during the time period of the present study (1987-1994). Notwithstanding this possibility, methods and findings from the present study provide insight
\end{abstract}

Received March 1, 2007.

Accepted June 29, 2007.

${ }^{1}$ Corresponding author: hcjuarez@correo.xoc.uam.mx about the complexity of genetic association and genotype $\times$ environment interactions between AFC and MY. Key words: dairy cattle, age at first calving, milk yield, genotype $\times$ environment interaction

Age at first calving (AFC) determines the beginning of the cow's productive life and influences her lifetime productivity (Ojango and Pollott, 2001). It has been proposed that AFC between 22 and 24 mo is optimal to minimize dystocia and to obtain adequate milk yield in first lactation (Hoffman, 1997). The AFC at younger ages reduces rearing costs, but milk yield depends on AFC, although the former effect diminishes in time. Hoffman et al. (1996) found that calving earlier than 22 mo of age had a negative influence on milk yield. Based on milk yield returns and rearing costs at different AFC, Nilforooshan and Edriss (2004) found that AFC of 23 to 24 mo was more profitable than 21 to 22 mo. Although AFC affects milk yield of cow and herd level, little attention has been paid to the study of genetic associations between these traits.

Genotype $\times$ environment interaction has been observed for milk yield (Cienfuegos-Rivas et al., 1999; Costa et al., 2000; Hayes et al., 2003), for protein and fat yields (Castillo-Juarez et al., 2002; Hayes et al., 2003), for the genetic association of milk yield with protein and fat yields (Castillo-Juarez et al., 2002; Raffrenato et al., 2003), as well as for fitness traits and their association with milk yield (Roxström et al., 2001; Calus et al., 2005; Windig et al., 2005; Beerda et al., 2007). The aim of this study was to evaluate the potential for genotype $\times$ environmental interaction for AFC and its relationship with mature equivalent milk yield (MY) in Holstein cows using complete information representing an intermediate herd environment and from 2 extreme herd environmental classes for milk.

The Animal Improvement Programs Laboratory of the USDA provided the data for this study. A total of 
Table 1. Means, SD, and number of records for variables in the complete data set and in low and high herd levels, with herds classified based on mean and herd SD mature equivalent milk yield

\begin{tabular}{|c|c|c|c|c|c|c|c|c|c|}
\hline \multirow[b]{2}{*}{ Variable } & \multicolumn{3}{|c|}{ Complete data set } & \multicolumn{3}{|c|}{ Low level herds } & \multicolumn{3}{|c|}{ High level herds } \\
\hline & Mean & $\mathrm{SD}$ & $\mathrm{n}$ & Mean & SD & $\mathrm{n}$ & Mean & SD & $\mathrm{n}$ \\
\hline Age at first calving (d) & 821 & 100 & 248,230 & 867 & 106 & 41,355 & 793 & 88 & 87,090 \\
\hline Mature equivalent milk (kg) & 9,916 & 1,944 & 248,230 & 8,450 & 1,448 & 41,355 & 10,821 & 1,946 & 87,090 \\
\hline
\end{tabular}

248,230 US Northeast DHI Holstein records from cows calving from January 1987 to December 1994 remained after edits, representing 588 sires in 3,042 herds. First lactation records including date of calving, cows with AFC between 18 and 36 mo, and MY were kept. Editing details and herd classification procedure into low or high level environments for MY (based on herd-yearseason combination of mean and SD for MY) were presented in Castillo-Juarez et al. (2000). High and low level represented the upper and lower quartile, respectively; hence $50 \%$ of the herd-year-season records were excluded from the analysis when comparing herd environments, but the complete data set was also analyzed. Means and SD for AFC and MY are presented in Table 1. The current mean AFC for US Holstein, near to 24 mo (Hare et al., 2006), is about 2 to 3 mo younger than during the timeframe of data from the present study. The current mean MY has increased 1,977 kg to 11,893 kg (Animal Improvement Programs Laboratory, 2007).

Mean number of records per sire, the number of herds and herd-year-season of calving classes for the complete data set and for the 2 data sets including high and low environments are shown in Table 2 . The potential differential use of sires within environmental classes was evaluated by weighting sire PTA from the complete data set by the number of daughters in each class and comparing the means using a Student's $t$-test. Daughter frequencies in the 2 classes were compared using a $\chi^{2}$ test.

The model used to estimate (co)variance components was a bivariate linear mixed sire model. In matrix notation $\mathbf{Y}=\mathbf{X} \boldsymbol{\beta}+\mathbf{Z u}+\mathbf{e}$, where $\mathbf{X}$ is a known indicator

Table 2. Mean number of daughters per sire, and number of herds and herd-year-season (HYS) of calving classes for the complete data set and for the data sets with low and high level environment herds, with herds classified based on herd mean and herd SD of mature equivalent milk ${ }^{1}$

\begin{tabular}{lrrrrrr}
\hline & \multicolumn{2}{c}{ Daughters per sire } & & \multicolumn{3}{c}{ Number of } \\
\cline { 2 - 3 } \cline { 5 - 6 } Data set & Mean & SD & & Herds & HYS & Records \\
\hline Complete & 422.2 & 722.4 & & 3,042 & 63,416 & 248,230 \\
Low level herds & 70.3 & 125.0 & & 766 & 14,158 & 41,355 \\
High level herds & 148.1 & 253.5 & & 759 & 17,793 & 87,090 \\
\hline
\end{tabular}

${ }^{1}$ Number of sires $=588$. matrix accounting for the fixed effects of herd-yearseason of calving, $\boldsymbol{\beta}$ is the unknown vector of fixed effects of herd-year-season of calving, $\mathbf{Z}$ is a known indicator matrix associating sire effects to the vector of observations $\mathbf{Y}, \mathbf{u}$ is the vector of unknown random sire effects, and $\mathbf{e}$ is the vector of residual random effects. Traits studied were AFC and MY. The same bivariate linear sire model was used to estimate the genetic correlations between the same trait in the 2 herd environment classes. This sire model was used for the following analyses: a) complete data set, b) low yield environment class, c) high yield environment class, and d) low and high environment classes combined. These analyses were performed to estimate the genetic (co)variance structure in the entire population (a), to estimate the genetic (co)variance structure within environment class (b) and (c), and using the likelihood ratio test (LRT) to compare a model with 4 (co)variances vs. a model with 8 (co)variances, 4 for each environmental class. Variance components were estimated using MTDFREML software (Boldman et al., 1995). The correlated response to selection was estimated as the regression of the expected breeding values of AFC on breeding values of MY within and across environments. Similarly, correlated responses to selection of MY on AFC were also calculated.

Two approaches were considered to compare the genetic (co)variance structures, heritabilities, and genetic correlations between low and high environment herds for the traits and time period studied. First, a LRT was used to compare the $2 \mathbf{G}_{\mathbf{o}}$ matrices from low and high environment classes. A significant test implies that 2 separate models better describe the genetic variation than a single model (i.e., there are $2 \mathbf{G}_{\mathbf{o}}$ matrices); and that there is evidence for genotype $\times$ environment interaction. Second, approximate standard errors for heritabilities and genetic correlation were calculated (Robertson, 1959; Swiger et al., 1964) and used to assess differences between these parameters in high and low environment herds.

Heritabilities, genetic and phenotypic correlations, and variance components for the complete data set and according to herd class are shown in Table 3 . The estimated heritability for AFC was high and larger for the complete data set than estimates obtained from the low 
Table 3. Heritabilities of age at first calving (AFC), genetic and phenotypic correlation with mature equivalent milk yield (MY) and the variance components for AFC, for the complete data set and the 2 data sets including low and high level environment herds, with herds classified based on herd mean and herd SD of $\mathrm{MY}^{1}$

\begin{tabular}{lccc}
\hline Item & Complete data set & Low level herds & High level herds \\
\hline Heritability & $0.474(0.012)$ & $0.195(0.010)$ & $0.329(0.012)$ \\
Genetic correlation & $-0.443(0.019)$ & $-0.309(0.028)$ & $-0.523(0.019)$ \\
Phenotypic correlation & -0.111 & -0.056 & -0.130 \\
Sire variance & 685.70 & 309.43 & 405.33 \\
Environmental variance & $5,105.90$ & $6,046.12$ & $4,527.13$ \\
\hline
\end{tabular}

${ }^{1}$ Approximate standard errors are given in parentheses.

and high herd environment classes. This resulted from a reduction in the sire variance and an increment in the environmental variance in the low-level herd class compared with the complete data set. Both variances were reduced in the high-level herd class, but the reduction in the sire variance was greater than that observed in the environment variance. A larger environmental variance in lower herd environments might be associated with less stringent management regarding age and $\mathrm{BW}$ at first insemination. In fact, AFC in the low herd environment was $74 \mathrm{~d}$ more than in high herd environment. The heritability for AFC differed between low and high herd levels $(P<0.01)$. The heritability estimates from both herd level classes and the complete data set were similar to those in previous reports $(0.22$; Allaire and Lin, 1980), (0.16; Moore et al., 1992), (0.38; Ojango and Pollott, 2001). However, other studies found heritability estimates less than 0.10 (Moore et al., 1991; Mäntysaari et al., 2002) with values as small as 0.02 (VanRaden and Klaaskate, 1993).

The phenotypic correlations between AFC and MY were small and negative for the complete data set $(-0.11)$ and also in both herd level classes, slightly lower in the high level herd class $(-0.13)$ than in the low level herd class $(-0.06)$. The phenotypic correlation between $\mathrm{AFC}$ and MY in other studies has been estimated inconsistently as small and negative $(-0.20$; Ojango and Pollott, 2001), (-0.09; Nilforooshan and Edriss, 2004), and small and positive (0.16; Moore et al., 1991). According to results from Ojango and Pollott (2001), early-maturing heifers are better milk producers. This may be related to the association between puberty and BW. Heifers with high genetic potential for growth or those reared in herds with better nutritional management reach puberty sooner, are mated earlier, and calve at younger ages. Hence, AFC performance is heavily influenced by management inputs. Less variation in AFC is expected when calvings are planned for a particular season or specific period of time.

The genetic correlations between AFC and MY were negative regardless of herd level. The genetic correlations were -0.44 in the complete data set, -0.31 in the low-level herd class, and -0.52 in the high-level herd class (LRT, $P<0.001$ ). These estimates are slightly larger than those in previous reports for Holstein cows that ranged from -0.20 to -0.33 (Moore et al., 1991; Pirlo et al., 2000; Mäntysaari et al., 2002; CienfuegosRivas et al., 2006), although positive genetic and phenotypic correlations between AFC and MY also have been reported in New Zealand Holstein cows (Grosshans et al., 1997) under grazing conditions with a controlled breeding season. Hodel et al. (1995) found that primiparous calving after 32 mo of age had poorer subsequent fertility compared with those calving at younger ages. On the other hand, too early calving $(<22 \mathrm{mo})$ carries negative consequences like dystocia associated with lighter BW at calving (Thompson et al., 1983), reduced fertility (Studer, 1998), milk fever, mastitis (Erb et al., 1985), low milk yield (Hoffman et al., 1996) and, in general, a low tissue reserves (Thompson et al., 1983).

The observed correlations in the complete data set were within the range of the estimated correlations in both herd level classes. The different heritability estimates for AFC and the changes in the genetic correlation between $\mathrm{AFC}$ and $\mathrm{MY}$ in the 2 herd level classes indicate the existence of genotype $\times$ environment interaction. Moreover, the correlation between AFC predicted breeding values from low and high environment herds was 0.69 . Although not a genetic correlation, this result supports the findings of Cerón-Muñoz et al. (2004) who estimated a genetic correlation of 0.78 for AFC between Brazilian and Colombian herds, indicating differences in sire ranking consistent with a genotype $\times$ environment interaction. Cienfuegos-Rivas et al. (2006) found that the genetic covariances between milk yield and AFC were negative within Mexico and the United States and positive between countries.

The correlated response for AFC to selection for MY in both herd level classes was smaller than that estimated from the complete data set (Table 4) representing an intermediate herd environmental level. Therefore, a nonlinear association of heritabilities estimates across environments was indicated. Data from a large herd of Jersey cattle in Kenya, which may represent a re- 
Table 4. Expected correlated responses for age at first calving (AFC) in days as a result of $1,000 \mathrm{~kg}$ of genetic gain in mature equivalent milk yield (MY), and expected correlated responses for MY in kilograms as a result of a 1-d genetic reduction in AFC, when selection is practiced within and across environments ${ }^{1}$

\begin{tabular}{|c|c|c|c|c|c|c|}
\hline \multirow[b]{4}{*}{ Response in class } & \multicolumn{3}{|c|}{$\mathrm{MY}^{2}$} & \multicolumn{3}{|c|}{$\mathrm{AFC}^{2}$} \\
\hline & \multicolumn{3}{|c|}{$\mathrm{AFC}^{3}$} & \multicolumn{3}{|c|}{$\mathrm{MY}^{3}$} \\
\hline & \multicolumn{6}{|c|}{ Selection on class } \\
\hline & Low & High & $\begin{array}{c}\text { Complete } \\
\text { data set }\end{array}$ & Low & High & $\begin{array}{l}\text { Complete } \\
\text { data set }\end{array}$ \\
\hline Low & $-27.0(2.0)$ & $-32.9(2.8)$ & $-41.9(3.8)$ & $7.7(0.6)$ & $16.2(1.1)$ & $14.6(1.0)$ \\
\hline High & $-14.4(1.0)$ & $-26.3(1.2)$ & $-31.1(1.7)$ & $5.0(0.4)$ & $15.8(0.7)$ & $13.3(0.7)$ \\
\hline Complete data set & $-15.3(1.1)$ & $-26.1(1.3)$ & $-32.6(1.9)$ & $3.5(0.3)$ & $10.4(0.6)$ & $9.2(0.5)$ \\
\hline
\end{tabular}

${ }^{1}$ Standard errors in parentheses.

${ }^{2}$ Trait selected.

${ }^{3}$ Response trait.

stricted environment, showed an annual genetic reduction in AFC of only 0.5 d (Musani and Mayer, 1997).

Results from the time period of this study indicated that heifers maturing at younger ages are better milk producers. Selection for MY would be expected to reduce $\mathrm{AFC}$ and, hence, to also reduce the rearing costs of replacement heifers. It is likely that management is the main reason for the observed differences between the herd level classes, as defined in this study. The favorable correlated response in AFC to selection for MY may be smallest in the low-level herd class, but results from the complete data set suggests that this favorable association is highest in intermediate herd environments. This outcome is in agreement with the findings of Windig et al. (2006) who noted that improving management does not invariably affect the genetic association between production and fertility traits. The larger heritability value for AFC obtained from the complete data set compared with within herd level class analyses (Table 3) indicated a nonlinear association of the genetic variation for AFC across herd level classes. Such spurious outcomes could arise if many sires were used exclusively in different herd level classes. However, there was no evidence for differential use of sires within the environmental classes in this study $(P>$ 0.25). Based on the expected correlated response, results from the present study indicate improved genetic and phenotypic associations between AFC and MY through better management, but with an intermediate optimum. Hence, if selection is based on MY, evidence from this study suggests that the magnitude of correlated change in AFC is expected to vary with herd environment class. Of course, caution is warranted because genetic relationships are dynamic, especially in populations undergoing selection. Current relationships may differ from those during the time period of the present study (1987-1994). Notwithstanding this possibility, methods and findings from the present study provide insight about the complexity of genetic association and genotype by environment interactions between AFC and MY.

\section{REFERENCES}

Allaire, F. R., and C. Y. Lin. 1980. Heritability of age at first calving. J. Dairy Sci. 63:171-173.

Animal Improvement Programs Laboratory. 2007. Trend in milk by Holstein or Red \& White calculated May 2007. http://aipl.arsusda. gov/eval/summary/trend.cfm Accessed Jun. 26, 2007.

Beerda, B., W. Ouweltjes, L. B. J. Sebek, J. J. Windig, and R. F. Veerkamp. 2007. Effects of genotype by environment interactions on milk yield, energy balance, and protein balance. J. Dairy Sci. 90:219-228.

Boldman, K. G., L. A. Kriese, L. D. Van Vleck, C. P. Van Tassell, and S. D. Kachman. 1995. A manual for use of MTDFREML. A set of programs to obtain estimates of variances and covariances. USDA Agric. Res. Service, Beltsville, MD.

Calus, M. P. L., J. J. Windig, and R. F. Veerkamp. 2005. Associations among descriptors of herd management and phenotypic and genetic levels of health and fertility. J. Dairy Sci. 88:2178-2189.

Castillo-Juarez, H., P. A. Oltenacu, R. W. Blake, C. E. McCulloch, and E. G. Cienfuegos-Rivas. 2000. Effect of herd environment on the genetic and phenotypic relationships among milk yield, conception rate, and somatic cell score in Holstein cattle. J. Dairy Sci. 83:807-814.

Castillo-Juarez, H., P. A. Oltenacu, and E. G. Cienfuegos-Rivas. 2002. Genetic and phenotypic relationships among milk production and composition traits in primiparous Holstein cows in two different herd environments. Livest. Prod. Sci. 78:223-231.

Cerón-Muñoz, M. F., H. Tonhati, C. N. Costa, J. Maldonado-Estrada, and D. Rojas-Sarmiento. 2004. Genotype $\times$ environment interaction for age at first calving in Brazilian and Colombian Holsteins. J. Dairy Sci. 87:2455-2458.

Cienfuegos-Rivas, E. G., P. A. Oltenacu, R. W. Blake, S. J. Schwager, H. Castillo-Juarez, and F. J. Ruiz. 1999. Interaction between milk yield of Holstein cows in Mexico and the United States. J. Dairy Sci. 82:2218-2223.

Cienfuegos-Rivas, E. G., P. A. Oltenacu, R. W. Blake, and H. CastilloJuarez. 2006. Fertility responses of Mexican Holstein cows to US sire selection. J. Dairy Sci. 89:2755-2760.

Costa, C. N., R. W. Blake, E. J. Pollak, P. A. Oltenacu, R. L. Quaas, and S. R. Searle. 2000. Genetic analysis of Holstein cattle populations in Brazil and the United States. J. Dairy Sci. 83:2963-2974.

Erb, H. N., R. D. Smith, P. A. Oltenacu, C. L. Guard, R. B. Hillman, P. A. Powers, M. C. Smith, and M. E. White. 1985. Path model of reproductive disorders and performance, milk fever, mastitis, 
milk yield, and culling in Holstein cows. J. Dairy Sci. 68:33373349 .

Grosshans, T., Z. Z. Xu, L. J. Burton, D. L. Johnson, and K. L. Macmillan. 1997. Performance and genetic parameters for fertility of seasonal dairy cows in New Zealand. Livest. Prod. Sci. 51:41-51.

Hare, E., H. D. Norman, and J. R. Wright. 2006. Trends in calving ages and calving intervals for dairy cattle breeds in the United States. J. Dairy Sci. 89:365-370.

Hayes, B. J., M. Carrick, P. Bowman, and M. E. Goddard. 2003. Genotype $\times$ environment interaction for milk production of daughters of Australian dairy sires from test-day records. J. Dairy Sci. 86:3736-3744.

Hodel, F., J. Moll, and N. Kuenzi. 1995. Analysis of fertility in Swiss Simmental cattle-Genetic and environmental effects on female fertility. Livest. Prod. Sci. 41:95-103.

Hoffman, P. C. 1997. Optimum body size of Holstein replacement heifers. J. Anim. Sci. 75:836-845.

Hoffman, P. C., N. M. Brehm, S. G. Price, and A. Prill-Adams. 1996. Effect of accelerated postpubertal growth and early calving on lactation performance of primiparous Holstein heifer. J. Dairy Sci. 79:2024-2031.

Mäntysaari, P., M. Ojala, and E. A. Mäntysaari. 2002. Measures of before and after breeding daily gains of dairy replacement heifers and their relationship with first lactation milk production traits. Livest. Prod. Sci. 75:313-322.

Moore, R. K., P. P. Kennedy, L. R. Schaeffer, and J. E. Moxley. 1991. Relationships between age and body weight at calving and production in first lactation Ayrshires and Holsteins. J. Dairy Sci. 74:269-278.

Moore, R. K., P. P. Kennedy, L. R. Schaeffer, and J. E. Moxley. 1992. Relationships between age and body weight at calving, feed intake, production, days open and selection indexes in Ayrshires and Holsteins. J. Dairy Sci. 75:294-306.

Musani, S. K., and M. Mayer. 1997. Genetic and environmental trends in a large commercial Jersey herd in the Central Rift Valley, Kenya. Trop. Anim. Health Prod. 29:108-116.
Nilforooshan, M. A., and M. A. Edriss. 2004. Effect of age at first calving on some productive and longevity traits in Iranian Holsteins of the Isfahan Province. J. Dairy Sci. 87:2130-2135.

Ojango, J. M. K., and G. E. Pollott. 2001. Genetics of milk yield and fertility traits in Holstein-Friesian cattle on large-scale Kenyan farms. J. Anim. Sci. 79:1742-1750.

Pirlo, G., F. Miglior, and M. Speroni. 2000. Effect of age at first calving on production traits and on difference between milk yield returns and rearing costs in Italian Holsteins. J. Dairy Sci. 83:603-608.

Raffrenato, E., R. W. Blake, P. A. Oltenacu, J. Carvalheira, and G. Licitra. 2003. Genotype by environment interaction for yield and somatic cell score with alternative environmental definitions. J. Dairy Sci. 86:2470-2479.

Robertson, A. 1959. The sampling variance of the genetic correlation coefficient. Biometrics 15:469-485.

Roxström, A., E. Strandberg, B. Berglund, U. Emanuelson, and J. Philipsson. 2001. Genetic and environmental correlations among female fertility traits and milk production in different parities of Swedish Red and White dairy cattle. Acta Agric. Scand., Sect. Anim. Sci. 51:7-14.

Studer, E. 1998. A veterinary perspective of on-farm evaluation of nutrition and reproduction. J. Dairy Sci. 81:872-876.

Swiger, L. A., W. R. Harvey, D. O. Everson, and K. E. Gregory. 1964. The variance of intraclass correlation involving groups with one observation. Biometrics 20:818-826.

Thompson, J. R., E. J. Pollak, and P. L. Pelissier. 1983. Interrelationships of parturition problems, production of subsequent lactation, reproduction, and age at first calving. J. Dairy Sci. 66:1119-1127.

VanRaden, P. M., and E. J. H. Klaaskate. 1993. Genetic evaluation of length of productive life including predicted longevity of live cows. J. Dairy Sci. 76:2758-2764.

Windig, J. J., M. P. L. Calus, B. Beerda, and R. F. Veerkamp. 2005. Influence of herd environment on health and fertility and their relationship with milk production. J. Dairy Sci. 88:335-347.

Windig, J. J., M. P. L. Calus, B. Beerda, and R. F. Veerkamp. 2006. Genetic correlations between milk production and health and fertility depending on herd environment. J. Dairy Sci. 89:1765-1775. 